\title{
DESARRAIGO DEL OJO: EVOLUCIÓN DEL ESPECTADOR COMO TURISTA DE LA IMAGEN EN EL SIGLO XIX
}

Javier Luri Rodríguez

Universidad de La Laguna

Data recepción: 2017/05/31

Data aceptación: 2018/05/21

Contacto autor: luri.javier@gmail.com

ORCID: https://orcid.org/0000-0003-2086-3797

\section{RESUMEN}

La actual relación del espectador con las imágenes se asienta en hábitos relacionados con el viaje de ocio. Este componente turístico de la imagen recreativa se empieza a manifestar con claridad a lo largo del siglo XIX, cuando el viaje comienza a popularizarse como divertimento. La gran variedad de espectáculos visuales desarrollados en este siglo tiene en común una inclinación a desconectar el espectador de su entorno para hacer que se sienta transportado. Atracciones decimonónicas como los panoramas o los dioramas, reflejan esta característica de la imagen como medio de transporte virtual; una peculiaridad propia también del actual ecosistema visual, como se hace especialmente patente en la imagen esférica y la realidad virtual.

Palabras clave: turismo, realidad virtual, imagen, panorama

\section{ABSTRACT}

The current relationship between spectator and image is founded on habits relating to leisure travel. The use of recreational images for the purposes of tourism began in the 19th century, when travel became a popular form of entertainment. The wide variety of visual spectacles staged during the course of the century all share a desire to disconnect the spectator from their environment and give them the sense that they were taking a trip. Nineteenth-century spectacles such as panoramas and dioramas exemplify this metaphor of images as visual transportation. The same can also be said of the current visual ecosystem, particularly in spherical images and virtual reality.

Keywords: tourism, virtual reality, image, panorama

Viajar virtualmente mediante la imagen es un anhelo del espectador que viene manifestándose con intensidad desde los últimos dos siglos. Este espíritu viajero del ojo está relacionado con una serie de cambios históricos, sociales y tecnológicos que conviene describir y contextualizar.

Hoy podemos visitar virtualmente rincones lejanos del planeta mediante la visualización de vídeos y fotos esféricas. Con gafas de realidad virtual la inmersión en estas imágenes nos hace aislarnos del mundo que nos rodea para situarnos con gran verismo en los entornos representados. Estas imágenes esféricas suponen un ejemplo central de esta cualidad de la imagen como medio de transporte, aunque dicha cualidad la encontramos, en cierta medida, también en el resto de imágenes de las que nos rodeamos. Estamos acostumbrados a dejarnos llevar por las imágenes. 
La mirada contemporánea es cosmopolita, viajera, cada vez más desapegada de su entorno natural. Es común estar contemplando gente o paisajes desconocidos y lejanos en cualquier red social para al instante siguiente apagar el móvil, coger un autobús y una vez dentro dejarnos transportar de nuevo por nuestro dispositivo o cualquier otra pantalla cercana. Nuestro ojo ya no es lo que era.

Nuestra forma de relacionarnos con el entorno visible ha sufrido modificaciones a lo largo de la historia. Desde principios del siglo XIX, una serie de cambios redefinieron al observador y marcaron el rumbo de las nuevas producciones visuales. Estas transformaciones implican al espectador y a las variadas imágenes que le rodean, ya que todo ello forma parte de un conjunto vitalmente interrelacionado que podríamos denominar "ecosistema visual".

Si bien el siglo XIX es el del nacimiento de la fotografía, el del cine, e incluso el siglo de los panoramas, no debe reducirse todo a que estas revoluciones en la tecnología visual generaron los cambios perceptivos que han configurado al espectador moderno, más bien, acorde a los estudios genealógicos de Foucault, deben entenderse estas innovaciones tecnológicas como manifestaciones de complejos cambios en las fuerzas y reglas que componen la propia práctica perceptiva. ${ }^{1}$ Por tanto, aunque el siglo XIX y sus aparatos visuales pueden servirnos como eje principal al que recurrir para contextualizar al espectador contemporáneo, parece necesario evitar lecturas históricas excesivamente lineales.

Este texto pretende destacar aspectos que han sido cruciales en el modelado del espectador y su entorno visual, que parten de lo que hemos llamado "desarraigo del ojo"z. Para ello se relacionará la puesta en circulación de la imagen como mercancía, con la conquista de la autonomía de la visión y, de manera más precisa, con los impulsos viajeros del ojo. Con esto, se trazará el contorno de un ojo voraz, extirpado, a la fuga y mareado.

\section{La imagen en circulación}

La tecnología visual decimonónica experimentó un significativo desarrollo alimentado por un público con marcada disposición a consumir imágenes. Este tipo de espectador ya podemos verlo reflejado en la temprana Edad Moderna en la que las instituciones pierden el monopolio de la imagen, rompiendo la antigua distancia que separaba hasta entonces al pueblo de las imágenes sagradas. Así como en la Edad Media una institución tenía el derecho exclusivo de administrar la exhibición y producción visual, con posterioridad lo visual fue y ha sido un producto disponible, que se ofrece al espectador, que se modela para el espectador. ${ }^{3}$

Tras la Edad Media, la imagen privada pasa a ocupar un lugar protagonista, se generaliza el uso del lienzo como soporte ligero y fácil de transportar. La imagen madura como producto óptimo para el intercambio. La enorme demanda de imágenes privadas religiosas durante el final de la Edad Media, ya requirió de técnicas como la xilografía y la calcografía que permitieron la producción de imágenes devocionales más económicas. A partir del siglo XV las ilustraciones científicas, como las artísticas, participaron en una creciente densificación iconográfica asociada a un renacimiento de la cultura; en el siglo XIX las impresiones a color ya se producen a gran escala. ${ }^{4}$

En la evolución de la imagen como producto óptimo para el intercambio podemos ver descrito el florecer del cosmopolitismo del ojo moderno.

El propio desarrollo de las técnicas de reproducción es una expresión de la tendencia viajera de la imagen. Al poner en movimiento una imagen, la mirada es la que se ve liberada de las ataduras espaciales; nuestro ojo se deja transportar a lugares. Este acercamiento del mundo a través de reproducciones ha ido modelando al espectador y a la propia imagen.

[...] acercar espacial y humanamente las cosas es una aspiración de las masas actuales tan apasionada como su tendencia a superar la singularidad de cada dato acogiendo su reproducción. Cada día cobra una vigencia más irrecusable la necesidad de adueñarse de los objetos en la más próxima de las cercanías, en la imagen, más bien en la copia, en la reproducción. Y la reproducción, tal y como la aprestan los periódicos ilustrados y los noticiarios, se distingue inequívocamente de la imagen. En ésta, la singularidad y la perduración están imbricadas una en otra de manera tan estrecha como lo están en 
aquélla la fugacidad y la posible repetición. Quitarle su envoltura a cada objeto, triturar su aura, es la signatura de una percepción cuyo sentido para lo igual en el mundo ha crecido tanto que incluso, por medio de la reproducción, le gana terreno a lo irrepetible. ${ }^{5}$

Las observaciones de Benjamin en la primera mitad del siglo XX, podrían parecen descripciones del actual panorama visual, en el que las pantallas nos han acercado cada lejano rincón del mundo. La inmediatez de internet y el formato digital parece haber abierto una ventana por la que el ojo puede fugarse hacia cualquier sitio, y gracias a la cual cualquier sitio o situación adquiere un nuevo sentido a su existencia: ser visto por otros, publicado y compartido.

Este tránsito de ojos y cosas pertenece, como decimos, a este valor de la imagen de producto adaptado para el intercambio, evolucionado para el movimiento y el consumo, valor del que no escapa ningún rincón observable, espacios que han pasado a ser vistos como parcelas a explotar, existencias disponibles.

La esencia de la técnica moderna pone al hombre en camino de aquel hacer salir de lo oculto por medio del cual lo real y efectivo, de un modo más o menos perceptible, se convierte en todas partes en existencias. ${ }^{6}$

Ver el mundo, desde sus objetos, vivencias y hasta sus paisajes, como algo almacenable y distribuible, convertir todo lo que existe en existencias, es un carácter distintivo (acaso patológico) de nuestra cultura. ${ }^{?}$

El entorno visible no puede abstraerse de este impulso que todo cosifica y administra. Los paisajes con los que se empezaba a comerciar con los panoramas decimonónicos, suponían una forma de control sobre el espacio y la visualidad de un público que empezaba a disponer de tiempo libre y dinero para pagarse bellas vistas, cómodas experiencias visuales de viajes y maravillas naturales, sin salir de la ciudad. Estos viajes virtuales vienen demandados por un público que se va formando en esta libertad visual. Mientras el tren se populariza, pero los grandes viajes aún son muy costosos para la mayoría, el ojo se va haciendo ya cosmopolita.
La modernización del siglo XIX está relacionada con el desarraigo producido por un capitalismo que lo convierte todo en móvil, que todo lo pone en circulación. Una "desterritorialización"8.

Tal nomadismo es parte esencial del ojo moderno, que ha ido despegándose de su espacio original.

Muchos alemanes han perdido su tierra natal, tuvieron que abandonar sus pueblos y ciudades, expulsados del suelo natal. Otros muchos, cuya tierra natal les fue salvada, emigraron sin embargo y fueron atrapados en el ajetreo de las grandes ciudades, obligados a establecerse en el desierto de los barrios industriales. Se volvieron extraños a la vieja tierra natal. ¿Y los que permanecieron en ella? En muchos aspectos están aún más desarraigados que los exiliados. Cada día, a todas horas están hechizados por la radio y la televisión. Semana tras semana las películas los arrebatan a ámbitos insólitos para el común sentir, pero que con frecuencia son bien ordinarios y simulan un mundo que no es mundo alguno. En todas partes están a mano las revistas ilustradas. Todo esto con que los modernos instrumentos técnicos de información estimulan, asaltan y agitan hora tras hora al hombre todo esto le resulta hoy más próximo que el propio campo en torno al caserío; más próximo que el cielo sobre la tierra; más próximo que el paso, hora tras hora, del día a la noche; más próximo que la usanza y las costumbres del pueblo; más próximo que la tradición del mundo en que ha nacido [...] La pérdida de arraigo procede del espíritu de la época en la que a todos nos ha tocado nacer. ${ }^{9}$

Aunque el texto de Heidegger es escrito en 1955, esta idea de desarraigo del individuo de su entorno inmediato para habitar los medios de comunicación y la imagen resulta perfectamente actual, y conviene incluir también en este contexto, valorando su carácter incoativo, al siglo XIX, en el que se culmina el profundo modelado que supuso la Revolución Industrial. Esta etapa de revoluciones técnicas y científicas, y de profundas transformaciones en las formas de actuar y de pensar de la sociedad configuraron a un nuevo observador, marcado desde entonces por un ojo desarraigado. 


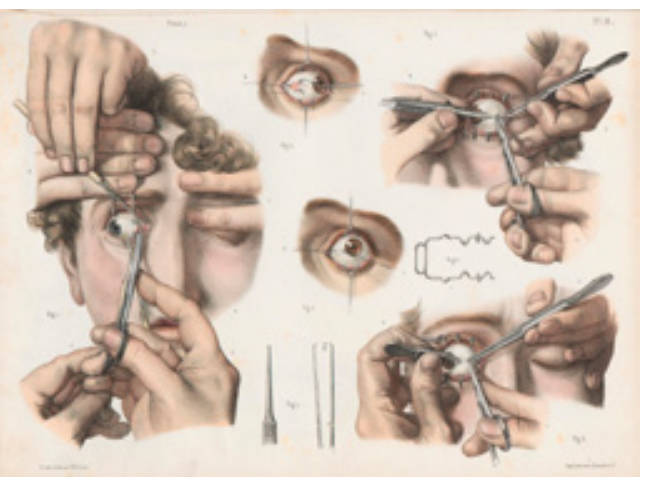

Fig. 1. Jacob, Nicolas-Henri, ilustración del libro Bourgey, Jean Baptiste. 1840. Traité complet de l'anatomie de l'homme: comprenant la médicine opératoire. (Vol. 7 Atlas). Paris: Delaunay. Ed. digital Biblioteca de la Universidad de Heidelbeg

\section{Ojo extirpado}

[...] en el siglo XIX se produce una reorganización del observador con anterioridad a la aparición de la fotografía. Lo que tiene lugar aproximadamente desde 1810 hasta 1840 es un desarraigo de la visión con respecto a las relaciones estables y fijas encarnadas por la cámara oscura. Si la cámara oscura, en tanto concepto, subsistía como base objetiva de verdad visual, diversos discursos y prácticas -en filosofía, en ciencia y en los procedimientos de normalización social- tienden a abolir los fundamentos de esa base a principios del siglo XIX. En cierto sentido, lo que ocurre es una nueva valoración de la experiencia visual: se le da una movilidad e intercambiabilidad sin precedentes, abstraída de todo lugar o referente fundantes. 10

Para esta abstracción de la visión fue condición indispensable la disociación de la vista del resto de los sentidos. La experiencia visual venía independizándose en esta dirección, mediante el mencionado protagonismo de la imagen privada y su optimización como mercancía móvil, descontextualizada, pero es en este siglo XIX donde se consolida esta separación del ojo (fig. 1).

Esta autonomización de la vista, que tuvo lugar en diferentes ámbitos, fue una condición histórica para la reconstrucción de un observador hecho a la medida de las tareas del consumo «espectacular». El aislamiento empírico de la visión no sólo posibilitó su cuantificación y homogeneización, sino que también permitió a los nuevos objetos de la visión (fueran mercancías, fotografías o el acto de percepción en sí mismo) asumir una identidad mistificada y abstracta, escindida de toda relación con la posición del observador dentro de un campo unificado cognitivamente. ${ }^{11}$

La visión fue en esta época estudiada como elemento aislado, disociado totalmente del resto de sentidos, lo que fue configurando una nueva concepción de la vista más autónoma y neutral en la que el observador es reducido a un estado teóricamente rudimentario.

Este aislamiento de la visión rompía con nociones imperantes hasta entonces apoyadas en pensadores como Descartes, que defendió la indisoluble conexión entre los sentidos, especialmente la vista y el tacto, ${ }^{12}$ y que intelectuales como Diderot se encargaron de reafirmar. ${ }^{13}$ Estas teorías inmediatamente anteriores al siglo XIX concebían el ojo más como anexo de una mente racional que como órgano fisiológico. En lo posterior, observaciones sobre la visión desde distintas disciplinas, especialmente la fisiología, fueron independizando la vista del tacto y del resto de los sentidos.

Tal disección de la mirada como elemento para la investigación, es perceptible también en la creación artística de la segunda mitad del siglo XIX. Cierto tipo de neutralidad óptica, que investiga y experimenta con el ojo del espectador, fue el objetivo que caracterizó a gran parte del arte pictórico de la época. Desde la pintura impresionista se construyeron profundos y variados estudios sobre óptica, la imagen, el color y la luz. Este interés por la visión no solo se sustanció en una profusa experimentación formal, sino que la propia mirada se convirtió en la temática predilecta de muchos de estos artistas. ${ }^{14}$

Muy diversas disciplinas reflejan, por tanto, este profundo cambio en el siglo XIX que atiende a la visión como elemento aislado. ${ }^{15}$ Esta neutralidad óptica, este análisis del espectador que vemos reflejado en la experimentación artística de la segunda mitad del siglo XIX, en los estudios fisiológicos de la época, y en otros observadores y pensadores coetáneos, guarda una estrecha relación con la formación de un observador capaz de consumir la gran cantidad de imaginería visual que estaba empezando a circular entonces. 
Estos nuevos análisis no solo aislaron la vista del resto de estímulos, también lograron separar lo percibido de su objeto.

El taumatropo, que el doctor John Ayrton Paris popularizó en Londres en 1825, hacía patente la naturaleza alucinatoria de la imagen. El sencillo objeto constaba de un disco en el que en cada cara había una imagen, mediante unos cordones en los extremos del disco se podía hacer girar éste, combinándose en nuestro ojo ambas imágenes, por ejemplo, el dibujo de un pájaro en una cara y el de una jaula en la otra hacía, al girar los cordones, que se viese el pájaro enjaulado.

El científico belga Joseph Plateau, por aquella época, realizó numerosos experimentos y desarrolló influyentes teorías sobre la "persistencia de la visión". En la década de 1830 construyó el fenaquistiscopio (literalmente "vista engañosa") en la que alrededor de un disco se dibujaban figuras en distintas posiciones, al girar el disco y mirando por unas rendijas, el observador podía ver el efecto de movimiento que creaba la rápida sucesión de figuras.

Estas rudimentarias imágenes animadas se empezaron a comercializar en Londres mientras surgían aparatos visuales similares como el estroboscopio, inventado por matemático alemán Stampfer o el zootropo de Wiliam G. Horner. Este último era un dispositivo que podían usar varios espectadores simultáneamente, situándose éstos alrededor de un cilindro que giraba con dibujos en su interior, a través de unas rendijas en el propio cilindro los espectadores disfrutaban del efecto de movimiento en secuencias a menudo de bailarines, malabaristas, boxeadores o acróbatas (fig. 2).

Estos dispositivos eran fruto de estudios sobre el observador mientras se convertían en productos de gran aceptación para un público inquieto y voraz.

La invención del estereoscopio estuvo también ligada a las investigaciones ópticas de la época. ${ }^{16}$ Hacia 1850 la difusión comercial de este aparato óptico se extiende por Europa y Norteamérica, dotando al público de unas experiencias visuales en las que la ilusión de presencia evoluciona hacia el efecto de imagen tangible.

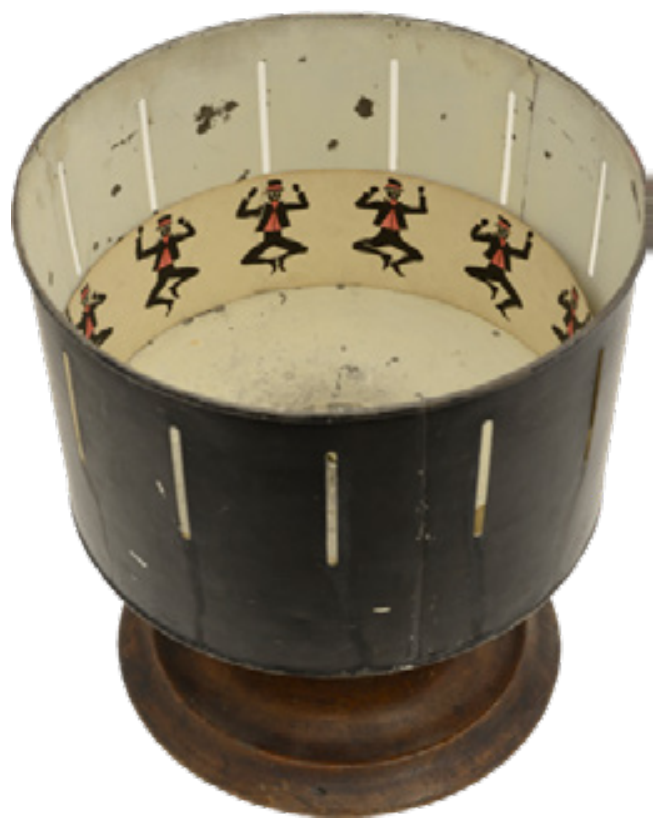

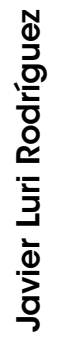

Fig. 2. Zootropo. Museum of the History of Science, Oxford

El estereoscopio logra un efecto tridimensional mediante dos imágenes con ángulos ligeramente distintos. El espectador mira esa imagen, situando un ojo en cada parte, dividiendo su mirada para participar en un proceso de reconstrucción. En esta imagen descompuesta se hace palmario el nuevo estatus de la imagen; el espectador estereoscópico no ve una copia, no ve una imagen enmarcada, sino que se relaciona con un aparato que recompone una imagen reproducida y fragmentada.

Se transgrede el punto de vista clásico, ese que se basaba en una perspectiva que ordena el espacio en base a la situación del observador frente a la obra; ahora el observador entra en el espacio virtual mientras la imagen simula la estructura anatómica de la mirada.

Queda disuelta ya cualquier conexión residual entre la imagen y su entorno físico, entre el espectador y el suelo que pisa.

\section{Ojo a la fuga}

El estereoscopio también refleja otra característica de las nuevas imágenes: la opulencia y la saturación. Para una óptima ilusión de presencia, 
el aparato necesita de imágenes con elementos que obstruyan la visión, que se interpongan en el campo de visión en los planos medios y cercanos. Si antes la perspectiva implicaba un espacio homogéneo y mesurable, este nuevo espacio aparece como desunificado, entrecortado y errático. La imagen estereoscópica más espectacular aparece llena de objetos, afín, por otro lado, al horror al vacío característico del burgués decimonónico.

El panorama, como espectáculo típico decimonónico, representaba ya esta nueva visualidad relacionada con la opulencia visual, así como la mencionada transgresión del punto de vista y la pérdida de contacto con el entorno inmediato ilustrada con la pérdida del marco en la imagen. En cuanto a la opulencia, baste destacar las dimensiones de los panoramas expuestos, que podían superar los 60 metros de altura y los 33 metros de diámetro, componiendo un gigantesco mirador plagado de detalles en los que el espectador podía recrearse. En lo que atañe a la ruptura con el punto de vista de la representación clásica, los panoramas se destacaron por otorgar al espectador una ubicuidad y movilidad sin precedentes, en ellos el público habitaba la imagen, la recorría físicamente, la mirada podía pasearse alrededor de unas instalaciones diseñadas para el movimiento del espectador por el paisaje pintado que le rodeaba. De hecho, tal opulencia no puede ser entendida sin el espíritu móvil de un ojo que demanda viajar por los detalles que, cuanto más variados y abundantes, más recorrido visual requieren.

La mirada en el siglo XIX es ya móvil y desconectada de un referente estable. Alejándose de modelos representacionales más inflexibles como la cámara oscura, en la que la imagen es reflejo directo del entorno del observador, se consolida un espectador familiarizado con experiencias ópticas que le transportan, le sacan de su contexto para situarle en autónomos entornos virtuales.

Esta separación del ojo de su entorno que venimos describiendo, viene acompañada por este desarrollo en la autonomía de la imagen, que va logrando, cada vez más, aislarse y aislar al espectador de su entorno directo.

Tras la revolución industrial, queda en las ciudades un paisaje opaco, de poca visibilidad. La funcionalización a la que se somete el espacio urbano limita al transeúnte la visión del horizonte o de perspectivas panorámicas. La vista cercana, los callejones y las esquinas configuran un nuevo paisaje más estrecho, entrecortado, de paso. Cierta nostalgia hacia la amplitud de los entornos rurales sumada a un claro ensalzamiento del dominio visual, contribuyó determinantemente en la generación de miradores, y vistas virtuales como la de los panoramas, que suponían una forma de recuperar el control del desmadejado espacio colectivo.

Esta necesidad de control y evasión que desarrolló el espectador en esta época fue la que demandó e hizo desarrollar ese tipo de imágenes sustitutas de lo real, pero, por otro lado, fue ese tipo de imágenes las que formaron ese nuevo espectador, y aún más, son esas imágenes la que construyeron la nueva realidad que nos rodea, un nuevo entorno visual. Sustentado en la gran variedad de tipos de imágenes y espectáculos visuales decimonónicos, el panorama, especialmente, representa un cambio en el ecosistema visual.

Un doble sueño se hizo realidad, uno de totalidady posesión; enciclopedismo de forma barata.

Pero haciendo la transición de la representación a la ilusión, el panorama también introdujo una nueva lógica cargada de consecuencias. Una de sus muchas culminaciones es la televisión moderna, cuya evolución ha sido particularmente esclarecedora. La imagen ya no pretende presentar la naturaleza en un estado ideal o incluso idealizado. Remplaza la realidad, elimina la necesidad de experiencia práctica, y pronto se priva a los observadores de experiencias personales que les ayuden a ver y adquirir conocimiento. Bajo la apariencia de entretenimiento, ilustración o educación, se forma un imaginario colectivo que, tarde o temprano, la propaganda, la publicidad o el comercio pueden llegar y reclamar. ${ }^{17}$

En los panoramas desaparece el punto de fuga único que ordenaba la representación clásica, en su lugar se otorga al espectador un espacio virtual por el que moverse, en el que fugarse él mismo. La propia fuga parece ser gran parte de la esencia de estas imágenes, como la de las estereoscópicas, o como con la imagen audiovisual actual: se trata de una vía de escape, un espacio atractivo ajeno a la realidad que rodea al espectador. 
Siempre ha existido lo que el poeta decimonónico Samuel Taylor Coleridge denominó la "suspensión voluntaria de la incredulidad que constituye la fe poética" 18; ante diversas manifestaciones artísticas el espectador adopta una actitud abierta a la irrealidad, su sentido crítico queda a un lado para dejarse llevar por una ficción y así sentirse inmerso en la obra, disfrutando del mundo ficticio creado para él. En esta suspensión de la incredulidad, el espectador, ignorando incoherencias y todo tipo de incompatibilidades, se deja convencer por la ficción para, a cambio, poder ser guiado por la narración literaria.

Es con los espectáculos visuales de esa época en adelante, en cambio, cuando tal suspensión viene alentada por un despliegue técnico especializado en atacar esa incredulidad. Ahora la virtualidad parece ser un fin en sí mismo, y no ya una actitud aportada por un espectador que, dejando de lado su desconfianza en lo que es o no creíble, se centra en escuchar una narración artística concreta. Con los panoramas, como con el estereoscopio, o incluso con el rudimentario zootropo, la ilusión no necesitaba narración, la mera alucinación es suficiente espectáculo. En estas imágenes la incredulidad del espectador no se suspende de manera totalmente voluntaria, el creador de estas representaciones es el que debe esforzarse en lograr un entorno lo más creíble posible; el público se deja transportar a entornos virtuales elaborados sin la necesidad de poner mucha imaginación por su parte. ${ }^{19}$ Aquí no tiene sentido pasar por alto incoherencias a favor de una narración, ya que esta no existe. En estas nuevas ficciones la ambientación es el único fin.

Es por esto que con los panoramas las escenas representadas no pertenecían a mundos ficticios y personajes fantásticos. El creador de los panoramas Robert Barker, tras un primer panorama exhibido en su casa sin mucho éxito, realizó la imagen "Londres desde el tejado de Albion Mills", que fue presentada en 1792 en una sala diseñada especialmente para la imagen, en la calle Castle Street 28 (calle que ahora es Charing Cross). En el periódico The Times apareció un anuncio de este espectáculo el 10 de enero de ese año en el que se utilizaba por primera vez la palabra "panorama". Esta exhibición, que resultó un gran éxito, presentaba al público una imagen de la propia ciudad que estaba habitando. Lo que podían ver los maravillados espectadores era una vista virtual, copia detallada y fiel de unas vistas situadas a menos de cuatro kilómetros de la sala donde se exponía la imagen.

Desde esos inicios, los panoramas atrajeron al público por la capacidad de estos para transportar. Aunque fuera un viaje virtual de solo unos pocos kilómetros de distancia, la imagen lograba sacar del sitio al espectador, y éste, sintiéndose transportado, actuaba entonces con la mirada curiosa y lúdica de un turista. Turista, en este caso, de su propia ciudad virtualizada.

Esta paradójica cercanía la encontramos también en el nacimiento del cine, cuando en 1895 se presenta la filmación, dirigida y producida por Louis Lumière, "Salida de obreros de la fábrica" en la "Sociedad para el fomento de la industria" de París (Société d'Encouragement à l'Industrie National). La escena se limitaba a mostrar, en plano fijo, cómo iban saliendo los distintos obreros de la fábrica Lumière y después cómo salía el coche de caballos de los patronos. No parece que fuera muy exótico para el público reunido en esa sede relacionada con la industria ver a personas salir de una fábrica situada en el mismo país. Sin embargo, en estos principios del cine, ya suponía un viaje gratificante tal recreación.

Si bien tanto los panoramas de Barker como las filmaciones de los hermanos Lumière pronto mostrarían paisajes más lejanos, incitando al público a vivir experiencias más viajeras, la cercanía entre lo representado y el público en estas primeras representaciones pone de manifiesto el poder que tiene este tipo de imágenes, que no necesitó para triunfar mostrar nada fantástico ni tan siquiera lejano.

La falta de ficción e incluso de narración era generalizada en los inicios del cine. Y aun cuando el cine representó obras ficticias, la narración no era algo central en la película, dependían de que las conociera el espectador o las narrase alguien durante la proyección.

Tenemos la impresión de que se daba por sabido que la historia y los personajes eran conocidos por el público, o que este conocimiento iba a serle proporcionado al margen de la proyección. 
[...] este apartamiento de la instancia narrativa, esta afirmación tácita de que la palabra del relato está fuera de la imagen -en la cabeza del espectador o en la boca del comentarista- afectará al cine durante veinte años o más. [...] Hoy damos por sabido que una película tiene que contar su propia historia, de modo que muchas veces nos sentimos incapacitados para leer estos relatos. ${ }^{20}$

Estas primeras películas no narrativas solían ser disfrutadas por los espectadores varias veces, en algunas ocasiones incluso con sucesivas proyecciones seguidas. Lo mismo ocurría con los panoramas, no se consumían de una sesión, sino que se visitaban repetidamente. El sentido de esta práctica no puede reducirse a un simple deseo de ser "sorprendido" una y otra vez por lo mismo, este tipo de imágenes parecen indicadas para ser vistas una y otra vez $y$, una y otra vez, sentirse transportado por ellas. No cabe duda de que todos estos artilugios visuales generaron una fuerte fascinación por la novedosa experiencia que procuraban; el propio ilusionismo del zootropo, del cine, o de los panoramas, ya fue suficientemente atractivo en un principio como para necesitar narración. Pero esta capacidad alucinatoria va más allá de la curiosidad de un espectador que se encuentra con lo imprevisto o que se ve atraído por los trucos de magia, el público dejó claro desde entonces su decidida atracción por la experiencia virtual recreativa, que, aunque puede enriquecerse con una buena narración, es una experiencia autónoma, capaz de operar con independencia a los mecanismos narrativos.

No son por tanto espectáculos que atraigan exclusivamente por lo novedoso de su técnica o lo sorprendente de su efecto, los entornos que nos acerca esta tecnología funcionan como deseables destinos hacia los que fugarse.

Este alejamiento de la narración para especializarse en la recreación de ambientes en los que situar al público también puede ilustrarse con el desarrollo de ciertos espectáculos que nacieron de la escenografía teatral pero que se desarrollaron hacia diversas formas de paisaje autónomo como el diorama y otros antecedentes similares.

Jean Nicolas Servandoni fue una figura muy relevante en el diseño y creación de decorados para teatro y ópera. En 1738, decidido a hacer algo diferente, presenta un espectáculo visual en el que lleva la pintura decorativa barroca a sus límites en un "teatro sin actores". Era de 21 metros de largo y 13 de ancho y mostraba el interior de la basílica de San Pedro en Roma (hoy Vaticano). Intercalaba pintura sobre lienzo, dispuesta en distintos trozos estratégicamente situados, con algunas partes con relieve tridimensional, todo para componer un detallista espacio para el deleite que, si bien no requirió de nuevos medios o técnicas ajenas al diseño escenográfico, sí logró elevar éstos a un nuevo nivel de perfección. Ahora el decorado no era un fondo para los actores, aquí solo actuaba el paisaje, que con sus efectos lograba trasladar al espectador.

Posteriormente el exitoso pintor Philippe-Jacques Loutherbourg, diseñó el Eidophusikon, que haría más literal eso de poner al paisaje a actuar. Este nuevo espectáculo, que también fue descrito como "teatro a pequeña escala sin actores", fue exhibido en Londres desde 1781 a 1793 por el mismo Loutherbourg, y por otros comenzado el S. XIX. La imagen esta vez era de apenas 2 metros de ancho, pero con 2,5 metros de profundidad. En este espacio se representaba un paisaje en recortes de cartón y otras superficies, con distintos materiales imitando las texturas de la naturaleza, todo colocado en una perspectiva muy estudiada. Los espectadores podían ver, al levantarse un telón, una escena natural al amanecer, con una elaborada iluminación. El paisaje comienza entonces a actuar ante el público, al aparecer una tenue luz en el horizonte que va cambiando la tonalidad de la escena, hasta que se ve aparecer un sol que ilumina primero las copas de los árboles y las colinas, y finalmente el paisaje entero, revelando una brillante mañana de verano. Las nubes se movían con naturalidad mientras los espectadores veían pasar el tiempo en aquel campo.

Los logrados efectos usaban complejos sistemas de iluminación con lámparas y vidrios de colores para cambiar las tonalidades, así como superficies semitransparentes móviles para las nubes. Los lienzos se movían sincronizados con las luces y los efectos sonoros creando una escena vívida. Loutherbourg mostró distintas escenas naturales incluida alguna de tormenta en el mar, con olas tridimensionales dotadas de movimiento, relámpagos y otros recursos efectistas. 
Otros paisajes artificiales dinámicos se lograban con pinturas sobre soportes transparentes como las de Franz Niklaus König que empezó en 1811 mostrando imágenes de su Suiza natal. Inspirándose en los por entonces muy populares panoramas, las llamó "diaphanoramas". La escena más grande que se conserva tiene apenas un metro de largo, pero la sensación de inmersión en sus paisajes era considerable, gracias a unos cambios lumínicos que transformaban el paisaje de manera muy natural.

Louis Daguerre, antes de conocer la técnica fotográfica que le llevaría a su popular daguerrotipo, también era pintor y decorador teatral. Supo ver los deseos de un público que venía reclamando ese tipo de espectáculos de presencia virtual, e invirtió mucho en el negocio de las experiencias visuales. Daguerre cogió construcciones escénicas que ya se estaban mostrando en la época, como las transparencias de König y las realizó en gigantescas proporciones, las llamó "dioramas" y las presentó en un edificio especial, acondicionado para todo un espectáculo de masas. Empezó en 1822 con dos imágenes de más de 21 por 13 metros, preparadas para ser iluminadas por detrás y por delante y así hacer aparecer y desaparecer detalles pintados en ambas caras. Mediante esta técnica de pintura opaca, pintura traslúcida, técnicas de manipulación de la luz y efectos sonoros, conseguía paisajes animados de gran naturalidad. Los más de trescientos espectadores contemplaron primero, sentados en sus butacas, cómo un paisaje suizo se desplegaba ante sus ojos en un amanecer que iba cambiando hasta el anochecer, un período de doce horas que se condensó en quince minutos de visionado de tal mirador artificial. Tras la contemplación de este paisaje, bajaba el telón y la plataforma en la que estaban los asientos del público giraba lentamente haciendo cambiar el punto de vista de los presentes para mostrarles una segunda escena. Estas actuaciones se daban diariamente entre las 11:00 y las 16:00h. y aunque no eran baratas tuvieron mucho éxito. El diorama de París estuvo casi veinte años funcionando, ofreciendo sus virtuales vistas al público.

Los espectadores ya no necesitaban ni siquiera caminar alrededor de la plataforma como en los panoramas, podían mantenerse sentados mien-

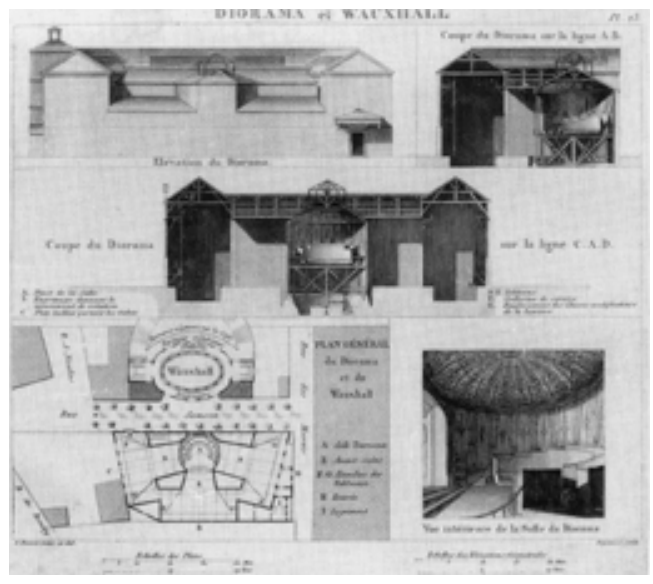

Fig. 3. Diorama de Daguerre en París. Architectonographie des Théâtres, A. Donnet, J. Origiazzi y J.A. Kaufmann, 1837-40 En Oettermann, Stephan. 1997. The Panorama: History of a Mass Medium. New York: Zone Books. p. 76

tras el paisaje se desarrollaba ante sus ojos y una vez disfrutada esa vista, los asientos giraban para mostrar otra nueva escena en la que recrearse. Posiblemente, aquellos viajeros virtuales a menudo llegaron a sentir que nunca se había visto tanto moviéndose tan poco.

El diorama en cierta forma culminó el proceso que venía desarrollando la tecnología visual de hacer viajar al ojo sin mover al individuo. Este desarraigo del ojo, este arrancar de su raíz original la mirada, logra su definitivo despegue con estos viajes inmóviles, desde las butacas de las salas de dioramas, para dejar el testigo a las butacas de un joven cine que inmediatamente después dejaría notar su gran potencial como medio de trasporte virtual (fig. 3).

Es muy representativo de los espectáculos decimonónicos, acompañar ese alejamiento de la narratividad con un acercamiento a la temática paisajística. Tal protagonismo del paisaje natural no solo lo encontramos desde los panoramas a los dioramas, sino que continúa con el cinematógrafo de la mano de las proyecciones de distintos lugares del mundo que los hermanos Lumière mostraron en sus sesiones, antes de que el cine se decantase de manera generalizada por un desarrollo como medio narrativo.

También encontramos cierto alejamiento de la narración y acercamiento al paisaje en la pintura del siglo XIX. El rechazo al racionalismo de la 


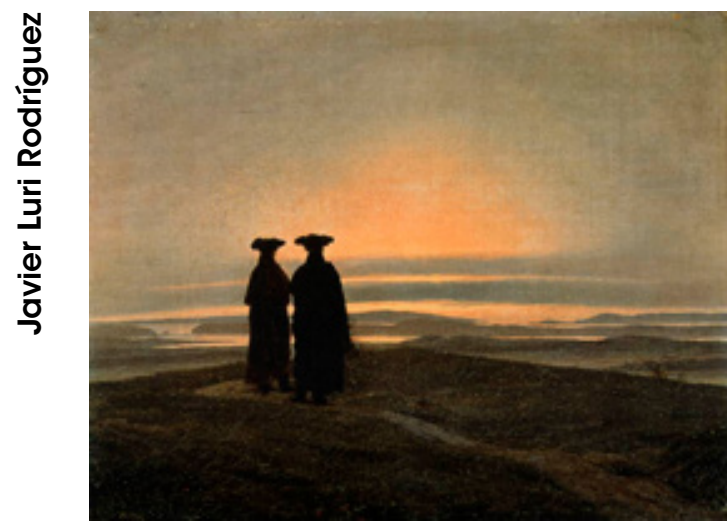

Fig. 4. Friedrich, Caspar David, Puesta de sol (hermanos), 183035. Óleo sobre lienzo, Hermitage Museum, St. Petesburg

Ilustración y al Neoclasicismo haría que el Romanticismo trajese la emoción y el paisaje natural a la primera línea de la creación pictórica.

Pinturas como las de Caspar David Friedrich reflejan la misma fascinación por el poder y la belleza de la naturaleza que encontramos en los distintos espectáculos visuales de su época. Tormentas sobrecogedoras como las recreadas con el Eidophusikon, o calmados paisajes donde la luz es protagonista como en la mayoría de los entornos representados en los dioramas, son también temas predilectos para los cuadros de la época. Son lugares que un público empezaba a reclamar como destinos, ya sea mediante la pintura, la fotografía, o cualquier otro medio capaz de facilitar tal viaje (fig. 4).

No obstante, aunque los cuadros fueron reflejo de las inquietudes visuales de su época, la imagen como se conocía hasta ahora, como la de los lienzos planos, no parece haber sido suficiente para el espíritu viajero del ojo decimonónico, ya que éste se caracterizó por su persevante innovación técnica en busca de la total sensación de presencia en sus imágenes.

Loutherbourg, por ejemplo, pasó de representar amaneceres y tormentas en sus cuadros, a animar el mismo tipo de escenas con su Eidophusikon.

Pero no solo muchos pintores se adaptaron a la nueva realidad visual cambiado de formato, la propia pintura del siglo XIX se transformó para participar de esa experimentación óptica, ilusionista, viajera. Los paisajes naturales estaban muy

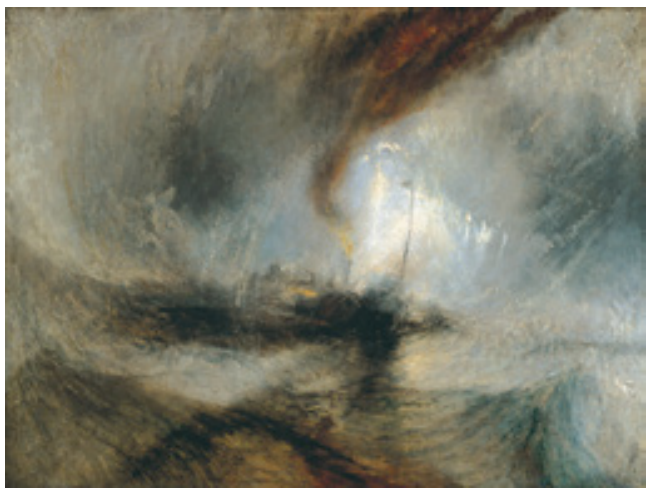

Fig. 5. Turner, William, Tormenta de nieve- Barco de vapor en la bocana de un puerto, 1842. Óleo sobre lienzo, Tate Gallery, London

presentes en los cuadros, pero muy frecuentemente enfocando lo remoto, cediendo el protagonismo al horizonte o a las nubes. Al enfocar a los cielos, la pintura se encontró con el vapor del ferrocarril, con el humo de las ciudades industrializadas, y, en general, con una nueva visualidad etérea.

El crítico John Ruskin describió la pintura de su tiempo explicando cómo la turbiedad y la mutabilidad caracterizaban un nuevo paisaje que encuadraba los elementos que momentáneamente cambiaban o se desvanecían.

[...] el cielo se considera de tanta importancia, que una masa principal del follaje, o un primer plano entero, se echa sin vacilar en sombra simplemente para realzar una nube blanca. De modo que, si se necesitaba un nombre general y característico para el arte paisajístico moderno, ninguno mejor podría ser inventado que "al servicio de las nubes". ${ }^{21}$

La pintura decimonónica vuela. Vuela, por un lado, por ese impulso viajero del espectador, ese que le estaba llevando a conquistar los cielos con los globos aerostáticos o a conquistar el horizonte con la locomotora. Pero vuela también por los espectáculos ópticos que estaban trayendo ilusionismo y virtualidad, sensaciones ajenas al suelo que pisaba el espectador. Como resultado de tales estímulos se configuraría una pintura alejada de lo terrenal, pero no elevada hacia lo divino, sino hacia la inmaterialidad cotidiana como la del humo de las ciudades o las nubes, cuerpos visibles pero sin superficie, como los cuerpos que 
se comenzaban a ver en numeroso espectáculos ópticos.

John Constable, experto pintor de nubes, ejemplifica en cada uno de sus cuadros el interés por tales elementos inmateriales y etéreos. ${ }^{22}$ Pero, tal como identificó Ruskin, es en los cuadros de William Turner donde podemos encontrar con mayor radicalidad la descorporeización de la imagen acontecida en el siglo XIX. Las nubes, nieblas, vapores y humos de Turner producen un efecto ilusionista y espectral que transciende la descripción atmosférica para dejar ver, entre brumas, las inquietudes ópticas propias de su época²3 (fig. 5).

Las imágenes que ofrecen los pintores románticos muestran paisajes naturales dinámicos donde la fugacidad se presenta como un elemento clave. Paisajes efectistas de lo fugaz, para espectadores deseosos de emoción y aventura. Fugacidad en la que fugarse.

$Y$ es que ese gusto por contemplar el paisaje no podemos disociarlo de lo que venimos describiendo como un deseo de fuga, un anhelo viajero que busca maximizar la sensación de estar en otro sitio.

El viajero aprecia la libertad de movimiento porque suele verse limitado en su vida cotidiana. Las limitaciones espaciales, pero también las temporales y otras opresiones que el hombre moderno siente como matriz de sus descontentos con la rutina diaria, son una fuente primordial de propulsión de los viajes turísticos. ${ }^{24}$

La historia de que a Robert Barker se le ocurrió el panorama cuando estaba encerrado en una prisión ${ }^{25}$ es tan significativa como el hecho de que, el mismo año de la aparición de sus panoramas, se presentara el revolucionario modelo de prisión circular, el panóptico de Bentham.

La búsqueda de una vía de escape parece una constante en la mirada de la época.

La literatura romántica también se puso al servicio de estas aspiraciones burguesas, ${ }^{26}$ pero en este siglo parece haber llevado las riendas del viaje virtual una joven industria visual que estaba desplegándose enérgicamente, nutrida de las demandas de un nuevo espectador.

Escapar del mundo cotidiano para disfrutar de vívidas sensaciones exóticas fue el gran reclamo de aquellas imágenes envolventes como los panoramas, los dioramas o las primeras proyecciones cinematográficas.

La ilusión de presencia pasa a ser una característica de primer orden en las representaciones visuales lúdicas. Una ilusión basada en la ya comentada cualidad alucinatoria de la imagen, esa que llamó tanto la atención de investigadores y consumidores de imágenes decimonónicos. El público, especialmente desde el siglo XIX, busca en la imagen esa impresión autónoma, independiente de su entorno sensorial directo, quiere sentirse en otro sitio, quiere, en definitiva, sentirse transportado por la imagen. ${ }^{27}$

\section{Mareos}

El deseo viajero del público de los panoramas, manifiesto también en disciplinas como la literatura o la pintura de la época, se convirtió en parte fundamental del carácter del consumidor de ocio decimonónico.

Durante el siglo XIX, la popularización del espíritu viajero y el desarrollo de la infraestructura relacionada con ello, llevó a los medios de transporte de masas a alcanzar niveles de sofisticación técnica y relevancia social sin precedentes. En este sentido, si el panorama podemos considerarlo representativo como medio de transporte virtual, el ferrocarril es un representante igualmente clarificador en el campo del transporte no virtual. Ambos medios ejemplifican con claridad la revolución puesta en marcha por ese espíritu viajero y que podemos relacionar con el actual turismo de masas en el que las infraestructuras y los consumidores han seguido creciendo en la misma dirección. ${ }^{28}$

Esta turistización conlleva una nueva relación del espectador con las imágenes, una en la que el paisaje ajeno suele funcionar como producto al que recurrir para evadirse del entorno inmediato. El turista, de imágenes virtuales o de viajes físicos, busca desconectar rápidamente de su cotidianeidad, para aprovechar el valioso tiempo libre que le deja su ajetreada vida laboral en consumir experiencias placenteras. El viaje en sí no suele ser más que un trámite incómodo hasta alcanzar el deseado destino. Mientras las agencias de viajes procuran viajes rápidos, directos y económicos, 


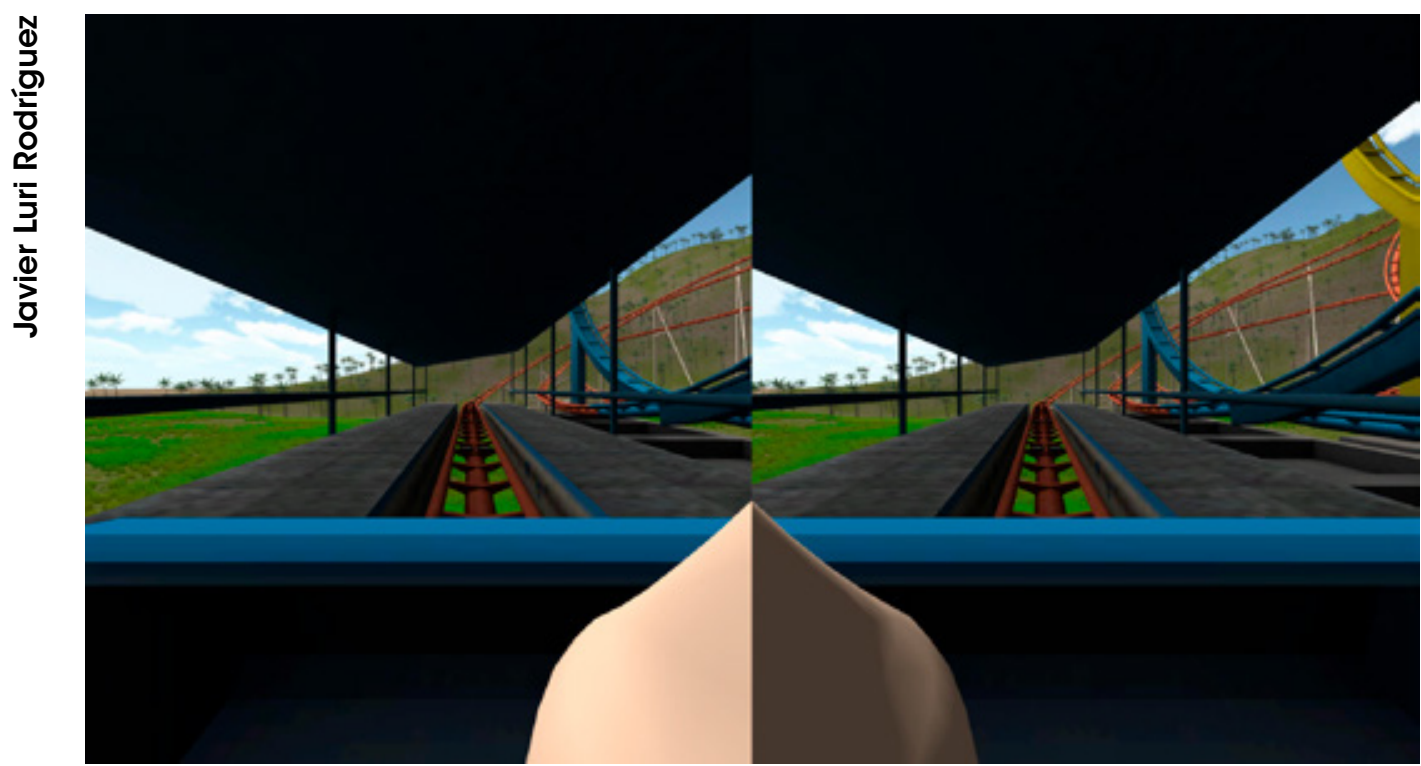

Fig. 6. Añadir una nariz en las imágenes virtuales para reducir el efecto "simulator sickness", David Matthew Whittinghill, Bradley Ziegler, James Moore, and Tristan Case, Universidad Purdue, Indiana

los entornos virtuales, de manera similar, ofrecen experiencias vicarias instantáneas.

Desde la época de los panoramas hasta la actualidad, mediante un recinto para pinturas envolventes o un globo aerostático, mediante unas gafas de realidad virtual o un avión, ha ido extendiéndose este hábito de desconectarse velozmente del mundo cotidiano. En esta urgente fuga de la rutina, se busca sentirse lo más transportado posible, de la manera más inmediata posible.

Parece lógico que tal velocidad, en los viajes reales, pero también en las imágenes alucinatorias, trajese los típicos efectos secundarios del viajero: mareos.

Los mareos propios del viaje son causados por información sensorial contradictoria que recibe nuestro cerebro, como por ejemplo sentirse quieto y ver el paisaje moverse velozmente. El sentido del equilibrio, la vista o nuestro propio movimiento ha estado tradicionalmente anclado. Hasta que empezamos a viajar. Con el viaje, el físico, pero también el virtual mediante la imagen, se desunen bruscamente estos lazos entre los distintos estímulos. El mareo es pues un síntoma físico ocasionado por la subversión de los sentidos.
En la época de los panoramas se dieron mucho estos efectos secundarios en los espectadores que, por ejemplo, enfocaban a un horizonte lejano virtual que en verdad estaba pintado en un cilindro cercano que le rodeaba. Estos vértigos se lograron atenuar separando las pinturas en cúpulas más grandes, tratando con ello también el desfase que sentía el observador al caminar por la plataforma del panorama y verse trasladado desproporcionadamente en el paisaje.

En 1793 Rober Barker, inaugurando su nuevo recinto construido para exponer varios panoramas simultáneos, presentó la imagen "Vista de la flota en Spithead", un paisaje marino lleno de barcos que rodeaba al espectador que, para mayor inmersión en la experiencia marina, se situaba en una plataforma disfrazada de cubierta de una fragata. La familia real acudió a contemplar el espectáculo del ya reconocido Barker, y la propia reina Charlotte admitió haberse sentido mareada cuando se encontró en medio de ese mar, rodeada de barcos. ${ }^{29}$

También han sufrido ocasionales mareos los que han contemplado imágenes esféricas mediante gafas de realidad virtual. Numerosas investigaciones tratan actualmente este efecto secundario. Algunas soluciones al "simulator sic- 
kness" pasan por añadir una nariz a la imagen para que su presencia ayude al cerebro a situarse en la escena, ${ }^{30} \mathrm{o}$ el desarrollo de sistemas para generar de manera dinámica una sombra periférica del campo de visión en los entornos virtuales, alterando los contornos de la imagen con una sombra variable que estrecha o amplía el campo de visión según la velocidad del movimiento dentro de las imágenes ${ }^{31}$ (fig. 6).

Como ante el envolvente mar del panorama de Barker que mareó a la reina, navegar por los entornos virtuales actuales puede ocasionar incómodos vértigos en el viajero. Pero estos desagradables síntomas suponen un valioso estímulo para el desarrollo de imágenes con mayor naturalidad, con lo que los mareos han sido y siguen siendo un importante indicador de aspectos a corregir para mejorar la experiencia viajera.
Los mareos y el desarrollo de soluciones por parte de la industria de la imagen, ilustran con claridad un tenaz esfuerzo por amoldar los sentidos a un ecosistema visual alejado de las raíces originales del ojo.

El impulso turístico del ojo, por un lado, y una complaciente industria del espectáculo por otro, alientan el desarrollo de un sistema de transporte virtual que va perfeccionándose en su objetivo de lograr un desplazamiento lo más confortable posible para el pasajero.

Este consumo de experiencias a través de la imagen se expande aceleradamente animado por nuestra creciente conectividad. Con la consolidación de este nuevo ecosistema visual, nuestro ojo desarraigado parece haber encontrado un entorno fugaz, dinámico, e inconmensurable donde echar nuevas raíces. 


\section{NOTAS}

1 [...] la tecnología se equivoca al considerar las herramientas por si mismas: las herramientas sólo existen en relación con las mezclas que ellas hacen posibles o que las hacen posibles. El estribo entraña una nueva simbiosis hombre-caballo, que entraña a su vez nuevas armas y nuevos instrumentos. Pues las herramientas son inseparables de las simbiosis o alianzas que definen un agenciamiento maquínico. Naturaleza-sociedad. Presuponen una máquina social que las selecciona y las incluye en su filum: una sociedad se define por sus alianzas y no por sus herramientas. Deleuze, Gilles, and Guattari, Félix. 2002. Mil mesetas: Capitalismo y esquizofrenia. Valencia: Pre-textos. p. 94.

2 Una idea semejante a esta premisa de desarraigo del ojo se desarrolla, en los términos de "ojo desorbitado" en: Díaz Cuyás, José. 2008. "Visiones aéreas: Robertson, fantasmagorero y aeronauta." Acto: Revista de pensamiento artístico contemporáneo, no. 4: 84-123. El autor describe cómo los vuelos aerostáticos y los nuevos espectáculos visuales de S XIX subrayan un panorama de descorporeización de las imágenes ligada a un anhelo de liberación de la mirada.

3 Sobre cómo cambió la fisionomía de las imágenes con esta disponibilidad del contenido iconográfico a los deseos del observador inaugurada al finalizar la Edad Media: Cfr. Belting, Hans. 2009. "El diálogo con la imagen. La era de la imagen privada en las postrimerías de la Edad Media." In Imagen y culto: Una historia de la imagen anterior a la edad del arte, 545-605. Madrid: Akal.

4 Cfr. Klingender, Francis. 1983. "Ilustración documental." In Arte y revolución industrial, 97-123. Madrid: Cátedra.

${ }^{5}$ Benjamin, Walter. 1989. "La obra de arte en la época de su reproductibilidad técnica." In Discursos Interrumpidos I, 15-57. Madrid: Taurus. pp. 24 y 25. En el ensayo La obra de arte en la época de su reproductibilidad técnica al que pertenece la cita, el autor se centra especialmente en analizar cómo esta reproductividad ha afectado al arte: [...] en los tiempos primitivos, y a causa de la preponderancia absoluta de su valor cultural, fue en primera línea un instrumento de magia que sólo más tarde se reconoció en cierto modo como obra artística; y hoy la preponderancia absoluta de su valor exhibitivo hace de ella una hechura con funciones por entero nuevas entre las cuales la artística -la que nos es consciente- se destaca como la que más tarde tal vez se reconozca en cuanto accesoria. Ibidem, p. 30

${ }^{6}$ Heidegger, Martin. 1994. "La pregunta por la técnica." In Conferencias y artículos, 9-37. Barcelona: Serbal. p. 26.

7 Heidegger ha visto en la voluntad de poder y en la imagen técnicocientífica del mundo una clave fundamental para interpretar la devaluación ontológica acontecida en Occidente. La relación que por medio de la técnica moderna el hombre establece con el mundo ya no hace honor al sentido de "bestellen", cuidar con solicitud, que pudo caracterizar la actitud-por ejemplo- del campesino en otro tiempo. Se trata ahora de un "stellen", de un poner la técnica a la naturaleza, de un impulso a someter todo lo dado y a convertirlo en disponible para el hombre, de transfigurar el mundo en algo almacenable, distribuible y domeñable. Sáez Rueda, Luis. 2001. Movimientos filosóficos actuales. Madrid: Trotta. p. 146

8 Cfr. Deleuze, Gilles, and Guattari, Félix. 1985. El Anti Edipo: Capitalismo y esquizofrenia. Barcelona: Paidós.

${ }^{9}$ Heidegger, Martin. 1989. Serenidad. Barcelona: Ediciones del Serbal., pp. 20-21.

${ }^{10}$ Crary, Jonathan. 2008. Las técnicas del observador: visión y modernidad en el siglo XIX. Murcia: Cendeac. p. 32.

${ }^{11}$ Ibídem, p. 39

12 [...] lo que dará ocasión al alma para sentir la situación, la figura, la distancia, la dimensión y otras cualidades parecidas que no se relacionan únicamente con un solo sentido, tal como es el caso de las que hasta ahora he mencionado, sino que son comunes al tacto y a la vista, asi como, de algún modo, a los otros sentidos. Descartes, René. 1980. Tratado del hombre. Madrid: Editora Nacional. p.85.

${ }^{13} \mathrm{El}$ uso del tacto como modelo para explicar la visión que Descartes usó en el siglo XVII lo apoyó explícitamente Diderot a mediados del siglo XVIII en el texto Carta sobre los ciegos para uso de los que ven, en el que articula su discurso en torno a las experiencias de las primeras operaciones de cataratas de la época y a conversaciones con ciegos de nacimiento como el ciego de Puiseaux: ¿Qué creéis que son los ojos?, le dijo el señor de... "Es -le respondió el ciegoun órgano en el que el aire actúa como el bastón sobre mi mano." [...] Señora, abrid La Dióptrica de Descartes y veréis los fenómenos de la vista relacionados con los del tacto, y figuras de óptica llenas de figuras de hombres ocupados en ver con bastones. Descartes, y todos los que vinieron después, no han podido darnos ideas más claras sobre la visión. Diderot, Denis. 2002. Carta sobre los ciegos seguido de Carta sobre los sordomudos. Valencia: Pre-textos. p.13.

${ }^{14} \mathrm{Si}$ existe algo profundamente nuevo en la pintura de Manet, Monet, Degas o Caillebotte, es el hecho de que sus obras hacen de la reflexión sobre la visión uno de sus temas centrales. El impresionismo «piensa la mirada» con una voluntad de innovación que no pretende ignorar la tradición, sino dialogar con ella. Esta «tematización de la mirada» es «moderna» por abarcar los límites de la visión y de la pintura. Stoichita, Victor I. 2005. Ver y no ver: La tematización de la mirada en la pintura impresionista. Madrid: Siruela. p. 12.

${ }^{15}$ Esta tendencia tiene, no obstante, contrapuntos reseñables como el interés por la sinestesia de los simbolistas y las pretensiones wagnerianas de "obra de arte total", todo ello también en el siglo XIX, siglo en el que además surgió el término de "sinestesia". La exploración de los límites de la percepción sensorial llevo a diferentes artistas, especialmente a final de siglo, a investigar sobre la conexión de los sentidos. Cfr. Hernández Barbosa, Sonsoles. 2013. Sinestesias: arte, literatura y música en el París fin de siglo (1880-1900). Madrid: Abada Editores.

${ }^{16}$ Charles Wheatstone y Sir David Brewster, asociados a la invención del estereoscopio, habían teorizado antes sobre ilusiones ópticas, teoría del color, postimágenes y otros fenómenos visuales. Cfr. Crary, Jonathan, op. cit., pp. 157-170.

${ }^{17}$ Comment, Bernard. 2000. The Painted Panorama. New York: Harry N. Abrams. p. 19. 
${ }^{18} \mathrm{Cfr}$. Coleridge, Samuel Taylor. 1817. Biographia Literaria: Biographical Sketches of my Literary Life \& Opinions. London: R. Fenner. (Cap. XIV).

${ }^{19}$ No obstante, cabe precisar que en entornos virtuales como los panoramas no se trataba de engañar totalmente al ojo, sino de crear vívidas experiencias con gran poder a la hora de movilizar la imaginación del espectador. En este sentido hablamos más de "ilusionismo" que de "trampantojo", de acuerdo con la distinción de d'Orange Mastai, que aclara que el trampantojo (término español equivalente al francés, de uso universal, "trompe l'oeil") busca la confusión del espectador, que por un momento toma lo pintado por real, mientras que el ilusionismo pictórico produce la sensación de estar en otro sitio, en un espacio imaginario que le invita a soñar. El trampantojo, elemento primordial en la historia del bodegón desde el siglo XVII pero presente en la pintura desde el siglo $\vee$ a.C. (según narraciones de Plinio el Viejo sobre la pintura de Zeuxis), es un deliberado intento de engañar con algún fragmento o elemento concreto, mientras que el ilusionismo pictóricoarquitectónico, muy frecuente en frescos romanos y en la pintura renacentista, lo que busca es modificar el espacio real por medio de la pintura. En otras palabras, el ilusionismo funciona como simulacro, no es un juego de engaño como el trampantojo. Cfr. Mastai, Marie-Louise d'Orange. 1975. Illusion in art: trompe I'oeil: a history of pictorial illusionism. New York: Abaris Books. p. 11.

${ }^{20}$ Burch, Nöel. 2011. El tragaluz del infinito: contribución a la genealogía del lenguaje cinematográfico. Madrid: Cátedra. p. 195-196.

${ }^{21}$ Ruskin, John. 1903. The works of John Ruskin. (Library Edition Volumes III-VII). Ed. E. T. Cook, and Alexander Wedderburn. London: George Allen. pp. 317-318.

${ }^{22}$ Constable estudió en profundidad el cielo y agregaba muchas veces notas meteorológicas a sus bocetos, creía que en una pintura de paisaje el cielo era "la nota clave, lo estándar de la escala y el órgano principal de lo sentimental". Parkinson, Ronald. 1998. John Constable: The Man and His Art. London: V\&A. p. 110.
${ }^{23}$ Visones aéreas [...]. En esta equivocidad entre el pictoricismo de Turner y el efecto óptico y espectral de la imagen, en estas vistas que se convierten en visiones, descubrimos en la nube un valor de puesta en escena, una nueva función de espectacularidad e ilusionismo, que ya no cabe relacionar como antaño con el teatro religioso y popular, sino con los recursos escénicos propios de nuevos espectáculos de óptica. Díaz Cuyás, José. 2010. "Notas sobre fantasmagoría y pintura." In Un art d'espectres: màgia $i$ esoterisme en el cinema dels primers temps, 23-45. Girona: Fundació Museu del Cinema-Col-lecció Tomàs Mallol, Ajuntament de Girona.

${ }^{24}$ Desde la antropología del turismo se ha descrito, como motivo principal del viaje de ocio, la búsqueda de experiencias auténticas apoyada en la autopercepción de la vida ordinaria como inauténtica. Cfr. MacCannell, Dean. 2003. "La modernidad y la producción de experiencias turísticas." In El turista: una nueva teoría de la clase ociosa, 25-51. Barcelona: Melusina.

${ }^{25}$ Cfr. Oettermann, Stephan. 1997. The Panorama: History of a Mass Medium. New York: Zone Books. p. 39.

${ }^{26}$ La literatura romántica está relacionada con esta aspiración de fuga. Los temas tratados pasan de la naturaleza a la mitología, pero podemos ver ejemplos de esta atracción por la fuga más literalmente en obras como Las penas del joven Werther (1774), obra de gran trascendencia en la época, y en la que las ideas de "prisión" y "libertad" son centrales. El Conde de Montecristo (1844) es otro clásico de la época que también se apoya en dichas pasiones. Friedrich von der Trenck se hizo muy popular en Europa por las aventuras sobre su encarcelamiento por amor y su posterior fuga, relatadas en sus memorias de 1787; un año más tarde Casanova publicó también un relato de su huida de las mazmorras de Venecia. Fugas menos literales, pero igualmente representativas de este espíritu viajero del Romanticismo plagan la literatura de final del siglo XVIII y principios del XIX por toda Europa.

La curiosidad por la otredad, en una época en que lo exótico, lo fantástico y lo insólito contribuyen de manera decisiva a un nuevo imaginario colecti- vo, produce un extraordinario aumento de "notas", "diarios", "epistolarios", "guías" y "memorias" de viajes. Díaz Larios, Luis F. 2002. "La visión romántica de los viajeros románticos." In Romanticismo 8: Los románticos teorizan sobre si mismos. Actas del VIII Congreso (Saluzzo, 21-23 de marzo de 2002), 87-99. Bologna: II Capitello del Sole.

${ }^{27}$ Aquellos que vivieron el nacimiento de la fotografía aceptaron con mucho gusto y como expresión de un logro social convertirse en observadores pasivos de la realidad, en espectadores inmóviles, en viajeros estáticos. [...] El viaje desde la fotografía suponía aceptar la imagen como un "medio de transporte". Vega, Carmelo. 2011. Lógicas turisticas de la fotografía. Madrid: Cátedra. pp. 97 y 101.

${ }^{28}$ El ferrocarril transformó el mundo de las tierras y los mares en un panorama que podría ser experimentado. [...] ahora que los viajes se habian vuelto tan cómodos y comunes, desvió la mirada de los viajeros hacia afuera y les ofreció el opulento alimento de las imágenes siempre cambiantes que eran lo único que se podía experimentar durante el viaje. Sternberger, Dolf. 1955. Panorama, oder Ansichten vom 19. Hamburg: Claassen. p. 50. Cit. por Schivelbusch, Wolfgang. 1986. The railway journey: The industrialization of time and space in the nineteenth century, California: Univ of California Press, p. 62.

${ }^{29}$ Así lo contó el cocreador de esta imagen, e hijo del inventor del Panorama, Henry Aston Barker: Cfr. Corner, George Richard. 1857. "The Panorama with memoirs of its inventor, Robert Barker, and his son, the late Henry Aston Barker." The Art Journal, vol. III: 46-47.

${ }^{30}$ Whittinghill, David Matthew, Ziegler, Bradley, Moore, James, and Case, Tristan. 2015. "Nasum Virtualis: A Simple Technique for Reducing Simulator Sickness." Game Developers Conference, San Francisco. https://www. gdcvault.com/play/1022287/TechnicalArtist-Bootcamp-Nasum-Virtualis

${ }^{31}$ Fernandes, Ajoy S., and Feiner, Steven K. 2016. "Combating vr sickness through subtle dynamic field-ofview modification." 3D User Interfaces (3DUI), 2016 IEEE Symposium on: 201210 
Desarraigo del ojo: evolución del espectador como turista de la imagen en el siglo XIX

\section{REFERENCIAS}

Belting, Hans. 2009. "El diálogo con la imagen. La era de la imagen privada en las postrimerías de la Edad Media." In Imagen y culto: Una historia de la imagen anterior a la edad del arte, 545-605. Madrid: Akal.

Benjamin, Walter. 1989. "La obra de arte en la época de su reproductibilidad técnica." In Discursos Interrumpidos I, 15-57. Madrid: Taurus.

Burch, Nöel. 2011. El tragaluz del infinito: contribución a la genealogía del lenguaje cinematográfico. Madrid: Cátedra.

Coleridge, Samuel Taylor. 1817. Biographia Literaria: Biographical Sketches of my Literary Life \& Opinions. London: R. Fenner.

Comment, Bernard. 2000. The Painted Panorama. New York: Harry N. Abrams.

Corner, George Richard. 1857. "The Panorama with memoirs of its inventor, Robert Barker, and his son, the late Henry Aston Barker." The Art Journal, vol. III: 46-47.

Crary, Jonathan. 2008. Las técnicas del observador: visión y modernidad en el siglo XIX. Murcia: Cendeac.

Deleuze, Gilles, and Guattari, Félix. 1985. El Anti Edipo: Capitalismo y esquizofrenia. Barcelona: Paidós.

Deleuze, Gilles, and Guattari, Félix. 2002. Mil mesetas: Capitalismo y esquizofrenia. Valencia: Pre-textos.

Descartes, René. 1980. Tratado del hombre. Madrid: Editora Nacional.

Díaz Cuyás, José. 2008. “Visiones aéreas: Robertson, fantasmagorero y aeronauta." Acto: Revista de pensamiento artístico contemporáneo, no. 4: 84-123.

Díaz Cuyás, José. 2010. "Notas sobre fantasmagoría y pintura." In Un art d'espectres: màgia $i$ esoterisme en el cinema dels primers temps, 23-45. Girona: Fundació Museu del CinemaCol-lecció Tomàs Mallol, Ajuntament de Girona.

Díaz Larios, Luis F. 2002. "La visión romántica de los viajeros románticos." In Romanticismo 8: Los románticos teorizan sobre sí mismos. Ac- tas del VIII Congreso (Saluzzo, 21-23 de marzo de 2002), 87-99. Bologna: Il Capitello del Sole.

Diderot, Denis. 2002. Carta sobre los ciegos seguido de Carta sobre los sordomudos. Valencia: Pre-textos.

Hernández Barbosa, Sonsoles. 2013. Sinestesias: arte, literatura y música en el París fin de siglo (1880-1900). Madrid: Abada Editores.

Fernandes, Ajoy S., and Steven K Feiner. 2016. "Combating vr sickness through subtle dynamic field-of-view modification." 3D User Interfaces (3DUI), 2016 IEEE Symposium on: 201-210.

Heidegger, Martin. 1989. Serenidad. Barcelona: Ediciones del Serbal.

Heidegger, Martin. 1994. "La pregunta por la técnica." In Conferencias y artículos, 9-37. Barcelona: Serbal.

Klingender, Francis. 1983. "Ilustración documental." In Arte y revolución industrial, 97-123. Madrid: Cátedra.

MacCannell, Dean. 2003. "La modernidad y la producción de experiencias turísticas." In El turista: una nueva teoría de la clase ociosa, 25-51. Barcelona: Melusina.

Mastai, Marie-Louise d'Orange. 1975. Illusion in art: trompe l'oeil: a history of pictorial illusionism. New York: Abaris Books.

Oettermann, Stephan. 1997. The Panorama: History of a Mass Medium. New York: Zone Books.

Parkinson, Ronald. 1998. John Constable: The Man and His Art. London: V\&A.

Ruskin, John. 1903. The works of John Ruskin. (Library Edition Volumes III-VII). Ed. E. T. Cook, and Alexander Wedderburn. London: George Allen.

Sáez Rueda, Luis. 2001. Movimientos filosóficos actuales. Madrid: Trotta.

Schivelbusch, Wolfgang. 1986. The railway journey: The industrialization of time and space in the nineteenth century, California: Univ of California Press. 
Stoichita, Victor I. 2005. Ver y no ver: La tematización de la mirada en la pintura impresionista. Madrid: Siruela.

Vega, Carmelo. 2011. Lógicas turísticas de la fotografía. Madrid: Cátedra.
Whittinghill, David Matthew, Bradley Ziegler, James Moore, and Tristan Case. 2015. "Nasum Virtualis: A Simple Technique for Reducing Simulator Sickness." Game Developers Conference, San Francisco. https://www. gdcvault.com/play/1022287/Technical-ArtistBootcamp-Nasum-Virtualis. 
